\title{
Geochemical reconstruction of late Holocene drainage and mixing in Kluane Lake, Yukon Territory
}

Janice Brahney (Corresponding Author), Department of Earth Science, Simon Fraser University, Burnaby, B.C., (604) 291-3062, jbrahney@sfu.ca

John J. Clague, Department of Earth Science, Simon Fraser University, Burnaby, B.C.

Brian Menounos, Department of Geography, University of Northern British Columbia

Thomas. W.D. Edwards, Department of Earth Science, University of Waterloo

Keywords: Lake sediment geochemistry; sediment provenance; constrained least squares;

discriminant analysis; Kluane Lake; Yukon Territory 


\begin{abstract}
The level of Kluane Lake in southwest Yukon Territory, Canada, has fluctuated tens of metres during the late Holocene. Contributions of sediment from different watersheds in the basin over the past 5000 years were inferred from the elemental geochemistry of Kluane Lake sediment cores. Elements associated with organic material and oxyhydroxides were used to reconstruct redox fluctuations in the hypolimnion of the lake. The data reveal complex relationships between climate and river discharge during the late Holocene. A period of influx of Duke River sediment coincides with a relatively warm climate around 1300 yr BP. Discharge of Slims River into Kluane Lake occurred when Kaskawulsh Glacier advanced to the present drainage divide separating flow to the Pacific Ocean via Kaskawulsh and Alsek rivers from flow to Bering Sea via tributaries of Yukon River. During periods when neither Duke nor Slims river discharged into Kluane Lake, the level of the lake was low and stable thermal stratification developed, with anoxic and eventually euxinic conditions in the hypolimnion.
\end{abstract}

\title{
Introduction
}

Kluane Lake is the largest lake in Yukon Territory, Canada, with an area of $409 \mathrm{~km}^{2}$ (Figure 1; Natural Resources Canada 2003). Geological evidence indicates that the size and level of Kluane Lake have fluctuated markedly throughout the Holocene. Drowned trees and submerged beaches indicate lake levels up to $30 \mathrm{~m}$ below present (Bostock 1969, Rampton and Shearer 1978a, Clague et al. 2006), and raised shorelines and beach deposits occur up to $12 \mathrm{~m}$ above present lake level (Bostock 1969, Clague 1981, Clague et al. 2006). 
The most recent rise in the level of Kluane Lake to its $+12 \mathrm{~m}$ highstand occurred in the $17^{\text {th }}$ century, during the Little Ice Age advance of Kaskawulsh Glacier. Dendrochronological evidence has constrained the time of this rise to a 50-year period beginning in AD 1650 and ending between AD 1680 and 1700 (Clague et al. 2006). Bostock (1969) hypothesized that, prior to the Little Ice Age, Kluane Lake drained southward through the Kaskawulsh River valley (Figure 1). The advance of Kaskawulsh Glacier blocked the southerly outlet and forced glacial meltwater and seasonal snowmelt from the glacier and its catchment directly to Kluane Lake via Slims River (watershed area $=1259 \mathrm{~km}^{2}$ ). Kluane Lake rose $12 \mathrm{~m}$ above its present level and overtopped the Duke River fan at the north end of the basin, establishing the current drainage route. The outflow incised the fan, lowering the lake to its present level.

The influence of Kaskawulsh Glacier on Kluane Lake prior to the $17^{\text {th }}$ century is presently unknown. The glacier advanced several times before the Little Ice Age (Borns and Goldthwait 1966; Denton and Stuiver 1966; Denton and Karlén 1977) and may have contributed meltwater to the lake at those times.

Duke River, with a watershed area of $631 \mathrm{~km}^{2}$, presently bypasses Kluane Lake, joining Kluane River 4 km north of the lake outlet (Figure 1). Aerial photographs and satellite images, however, reveal abandoned Duke River channels extending to the northwest shore of Kluane Lake near Burwash Landing, but it is not known when the channels were last active.

Geochemistry of lake sediments is a complex function of processes occurring within the lake and the surrounding catchment. The concentrations of dissolved solutes and sediment originating from the watershed are modified during transport, deposition, 
and early diagenesis. The elemental chemistry of lake sediments can record details about weathering, runoff, lake productivity, $\mathrm{pH}$, and redox conditions (Engstrom and Wright 1984; Boyle 2001). Climate change and associated watershed drainage processes can influence the types of sediments that enter the lake, as well as limnological characteristics such as lake temperature, depth, and redox conditions. Sediment geochemistry can also be used to fingerprint sediment sources in the watershed (e.g., Mosser 1991; Collins et al. 1997, 1998).

We use sediment geochemistry to provide insights into the relationship between historical climate change and drainage in the Kluane Lake basin. In addition, we infer changes in mixing depths, coincident with fluctuations in lake level.

\section{Study area}

Kluane Lake is located within Shakwak Trench in southwest Yukon Territory (Figure 1). The Kluane Ranges to the west are the easternmost range of the St. Elias Mountains. The Ruby Range to the east is part of the Yukon Plateau. The St. Elias Mountains support the largest ice fields and glaciers in North America, including Kaskawulsh and Donjek glaciers, which terminate, respectively, $20 \mathrm{~km}$ south and $40 \mathrm{~km}$ west of Kluane Lake.

The Denali fault extends in a northwesterly direction along the west side of Kluane Lake. It separates sedimentary and volcanic rocks of the Alexander terrane in the Kluane Ranges on the west side of the lake from high-grade metamorphic rocks of the Yukon-Tanana terrane in the Ruby Ranges to the east (Campbell and Dodds 1982). Thick glaciofluvial and glaciolacustrine sediments dating to the last glaciation (Kluane 
Glaciation) and one or more earlier glaciations underlie Kluane Lake and border it to the east.

During summer, when Slims River discharge is greatest due to melt of snow and ice, Kluane Lake typically rises 1-2 $\mathrm{m}$ above its winter level. Slims River is the dominant source of sediment to the southern portion of the lake. A sediment plume of glacial rock flour transported by Slims River covers much of the southern part of the lake during icefree periods. The rock flour is derived from both bedrock and sediments in the Slims River watershed. Turbid water from Slims River is denser than the lake water and sinks as it flows outward (Bryan 1972). Bottom waters are thus well aerated and the lake mixes throughout the summer. Silt in overflow and interflow plumes derived from Slims River rains out onto the floor of the southern half of the lake during summer and fall. Deposition of silt is restricted to water depths greater than $5 \mathrm{~m}$, and most of it occurs at depths greater than $10 \mathrm{~m}$. Currents are too vigorous at shallower depths for silt to accumulate there. Large amounts of silt and sand are carried from the slope of the Slims delta into deeper parts of the southern half of the lake by turbidity currents. Other sediment sources include Gladstone Creek at the northeast corner of the lake, Silver Creek at the south end of the lake, and several ephemeral streams that flow across large fans into the lake along its west side.

\section{Methods}

Core collection and analysis

Thirteen percussion cores, 11 from Kluane Lake, one from Cultus Bay, and one from Grayling Lake, were collected in July 2004; four of the 13 cores were used in this study 
(Figure 2). Six or more suspended sediment and floodplain samples were collected from Slims River, Silver Creek, Bock’s Creek, and Duke River. In addition, a representative sample of glaciolacustrine silt was collected from the east side of the lake. All cores were split and analyzed at a high resolution for bulk physical properties. Three Kluane Lake cores $(08,10$, and 36) and the Cultus Bay core (26) were selected for geochemical analysis. Plug samples, $1 \mathrm{~cm}$ in diameter, were taken from each core at intervals of 6-10 $\mathrm{cm}$, depending on the stratigraphy.

A test was conducted to determine if bulk elemental geochemistry is affected by elements in the organic or oxyhydroxide fraction of the sediments. Samples from core 10 were treated first with tetra-sodium pyrophosphate $\left(\mathrm{Na}_{4} \mathrm{P}_{2} \mathrm{O}_{7}\right)$ to remove metals associated with organic matter. Pyrophosphate does not attack sulfides and it does not dissolve amorphous iron oxyhydroxides (Ross and Wang 1993). Sodiumcitrate/dithionite $\left(\left(\mathrm{Na}_{3} \mathrm{C}_{6} \mathrm{H}_{5} \mathrm{O}_{7}\right) \cdot\left(\mathrm{Na}_{2} \mathrm{~S}_{2} \mathrm{O}_{4}\right)\right)$ was used as a reducing agent to remove $\mathrm{Fe}$ and Mn oxyhydroxides. Magnetite and silicates are not dissolved by this treatment (Ross and Wang 1993). The residual sediments were washed with distilled water and aspirated until neutral $\mathrm{pH}$ was achieved before the next digestion and final analysis. Major and trace elements in the extracts, residual sediment, and bulk untreated sediment were analyzed using an inductively coupled plasma-mass spectrometer (ICP-MS) and an inductively coupled plasma-atomic emission spectrometer (ICP-AES) at the Ontario Geological Survey Geosciences Laboratory. Trends of some elements in the bulk sediment samples and the treated residual sediment differ, thus the procedure outlined above was used to analyze the remaining lake and stream samples. 
Plant macrofossils were radiocarbon dated by the AMS method at Beta Analytic and IsoTrace laboratories. All dates are reported as calibrated ages. Additional dating control is provided by the White River tephra, which is about 1150 years old (Clague et al. 1995). The tephra, ${ }^{14} \mathrm{C}$ ages, and the tree-ring ages for the recent rise of Kluane Lake, rising above present level at $1650 \mathrm{AD}$, were used to estimate sedimentation rates and dates of major events recorded in the cores.

Data analysis

Principal component analysis, cluster analysis, discriminant analysis, Euclidean distance metrics, and sediment unmixing models were used to cluster sediment intervals and ascribe them to a particular sediment source. Principal component analysis was performed using singular value decomposition on the covariance matrix. The analysis was done on the residual stream sediment data to determine if individual streams had unique principal factors, and on core data to determine whether elemental associations in principal components are related to particular stream sources. The non-hierarchical Kmeans cluster method was used on the residual data to group sediment samples. Cluster centres were iteratively defined and calculated using the Euclidean distance metric. To assign each sediment interval to a dominant sediment source, we used both multi-group discriminant analysis and unweighted Euclidean distances, E:

$\mathrm{E}=\sqrt{\sum\left(S_{i}-C_{i}\right)^{2}}$

where $S_{i}$ is the stream source concentration of element $i$, and $C_{i}$ is the core interval concentration of element i. Finally, constrained least squares analysis was performed to 
determine the relative contribution of each stream to specific core intervals. Calculations are similar to those of Bryan et al. (1969). Composite element concentrations were used to minimize the error of proportional stream contributions to each core sediment interval. Constraints are such that each stream source proportion must be:

$0 \leq \mathrm{S}_{\mathrm{i}} \leq 1$

$\sum_{i=1-4}^{n=i} S_{i}=1$

\section{Results}

Core descriptions

Core 36 was collected near the southeast end of Kluane Lake at a depth of $36 \mathrm{~m}$ (Figure 2). The core is $240 \mathrm{~cm}$ long and comprises three units (Figure 3). Unit $1(240-97 \mathrm{~cm}$ ) consists of light grey silt (Munsell colours 5Y6/1 and 5Y5/1) with black laminae up to 1 mm thick. Black laminae are most common between 120 and $97 \mathrm{~cm}$ depth. Light grey laminae from 120 to $97 \mathrm{~cm}$ are coarser grained than those lower in the core. A piece of wood at $219 \mathrm{~cm}$ depth yielded a radiocarbon age of $3910 \pm 80{ }^{14} \mathrm{C} \mathrm{yr} \mathrm{BP}(4570-4090 \mathrm{cal}$ yr BP; Table 2.1). Unit 1 interfingers with unit $2(96-65 \mathrm{~cm})$, which consists of massive brown silt (7.5YR4/1 - 7.5YR4/2) with several fine sand laminae. The White River tephra occurs at $88 \mathrm{~cm}$ depth. Unit 2 is abruptly overlain by unit 3, which consists mainly of light olive-grey clayey silt (5Y6/1-2). Darker laminations (5Y4/1) from 1 to $5 \mathrm{~mm}$ thick occur throughout the unit. Sedimentation rates in units 1 and 2 are 0.04 and $0.03 \mathrm{~cm} \mathrm{yr}^{-1}$, respectively, and increase to $0.2 \mathrm{~cm} \mathrm{yr}^{-1}$ in unit 3 . 
Core 08 was collected at a depth of $25 \mathrm{~m}$ near the east shore of Kluane Lake between Christmas and Cultus bays (Figure 3). It is $63 \mathrm{~cm}$ long and comprises four units. The base of the core and the material found in the core catcher are coarse sand. Unit 2 $(63-34 \mathrm{~cm})$ consists of laminated fine to medium grey sand (10Y2.5/1) with a silty section between 61 and $54 \mathrm{~cm}$ depth. White River tephra occurs at $39 \mathrm{~cm}$, and additional chronological control is provided by a radiocarbon age of $1660 \pm 40{ }^{14} \mathrm{C}$ yr BP (1690$1500 \mathrm{cal} \mathrm{yr} \mathrm{BP)} \mathrm{at} 50.5 \mathrm{~cm}$. The contact between units 2 and 3 is gradational and interlayered. Unit $3(33-17 \mathrm{~cm})$ is laminated brown silt and very fine sand $(2.5 \mathrm{Y} 5 / 2$ and $2.5 \mathrm{Y} 3 / 3)$ with distinct bright orange layers (10YR5/6). Unit 3 is sharply overlain by unit $4(16-0 \mathrm{~cm})$, which is composed of laminated light olive-grey clayey silt $(5 \mathrm{Y} 5 / 2-3)$ with pale yellow beds (5Y5/2) $1-1.5 \mathrm{~cm}$ thick. Sedimentation rates increase from $0.02 \mathrm{~cm} \mathrm{yr}^{-1}$ in units 2 and 3 to $0.05 \mathrm{~cm} \mathrm{yr}^{-1}$ in unit 4 .

Core 10 was collected in $33 \mathrm{~m}$ of water on the east side of the lake, north of Cultus Bay. The core is $108 \mathrm{~cm}$ long and consists of four units (Figure 3). Unit 1 (108-69 $\mathrm{cm})$ and unit $2(68-36 \mathrm{~cm})$ are upward-fining, light grey, laminated silts (5Y4/1). The contact between the two units is gradational. Unit $3(35-19 \mathrm{~cm})$ is brown silt with several orange laminae (2.5YR4/6). Unit 3 and 4 are separated by a 2-cm-thick layer of White River tephra. Unit $4(18-0 \mathrm{~cm})$ comprises light olive-grey clayey silt $(5 \mathrm{Y} 4 / 2)$ with diffuse orange laminae.

Core 26 was collected in Cultus Bay in 14 m of water. Cultus Bay is separated from Kluane Lake by a spit that is breached at its south end. The core is $180 \mathrm{~cm}$ long and consists of five units (Figure 3). Unit 1, from the base of the core to $156 \mathrm{~cm}$ depth, is coarse sand with forest litter at $177 \mathrm{~cm}$. The forest litter includes conifer needles, detrital 
wood fragments, and rootlets. This unit is sharply overlain by unit $2(155-140 \mathrm{~cm})$, which consists of fine to medium sand and scattered plant detritus. Unit $3(139-53 \mathrm{~cm})$ marks the transition to lacustrine sedimentation and is composed of organic grey silt (5Y2.5/15Y3/1) with fine sand laminae. Several black streaks and laminations, roots in growth position, and plant detritus occur near the base of this unit. A piece of wood at $139 \mathrm{~cm}$ and another at $177 \mathrm{~cm}$ returned identical radiocarbon ages of $1180 \pm 40{ }^{14} \mathrm{C}$ yr BP $(1180-$ 980 cal yr BP). Unit $4(52-42 \mathrm{~cm})$ consists of rhythmically laminated light grey silt (5Y5/1) with $22-25$ couplets. Unit $5(41-0 \mathrm{~cm})$ is weakly laminated light grey silt (5Y2.5/1 - 5Y4/1) with scattered black spots and streaks. A sharply bounded bed with low organic content occurs at $37-39 \mathrm{~cm}$ depth.

Elemental abundances

\section{Residual}

In core 36, major changes in element abundances occur at 153, 97, and $65 \mathrm{~cm}$ (selected analytical data are shown in Figure 4). Phosphorus, $\mathrm{Ca}$, and $\mathrm{Na}$ increase from $65 \mathrm{~cm}$ to the surface; high values of these elements were also obtained in samples at 159 and 203 $\mathrm{cm}$. Calcium and Sr co-vary in units 1 and $2\left(\mathrm{r}^{2}=0.82\right)$, likely reflecting the presence of calcite.

Concentrations of $\mathrm{Al}, \mathrm{Ba}, \mathrm{Cs}, \mathrm{Ga}, \mathrm{K}, \mathrm{Li}, \mathrm{Rb}, \mathrm{Sn}, \mathrm{Th}, \mathrm{Tl}, \mathrm{U}$, and $\mathrm{W}$ increase from $97 \mathrm{~cm}$ to the top of the core. Silver, $\mathrm{Hf}, \mathrm{Nb}, \mathrm{Sb}, \mathrm{Ti}, \mathrm{Y}, \mathrm{Zr}$, and the lanthanide elements have relatively low concentrations in unit 3 , and higher, non-varying concentrations through the remainder of the core. Cobalt, $\mathrm{Cr}, \mathrm{Fe}, \mathrm{Mg}, \mathrm{Mn}, \mathrm{Ni}, \mathrm{Sc}, \mathrm{V}$, and $\mathrm{Zn}$ co-vary, with generally low values in unit 3 and in single samples at $159 \mathrm{~cm}$ and $203 \mathrm{~cm}$. Molybdenum, S, and organic carbon co-vary in unit 1 and increase from 130 to $97 \mathrm{~cm}$. 
Cores 10 and 08 show similar trends to core 36 . Elements associated with clay minerals ( $\mathrm{Al}, \mathrm{Ba}, \mathrm{K}$, and $\mathrm{Rb}$ ) increase upward in these cores, whereas $\mathrm{Mn}, \mathrm{Ti}$, and $\mathrm{Y}$ decrease upward. Calcium and Sr co-vary from the base of the cores to units 3 and 4 in cores 08 and 10, respectively. Sulfur increases from 80 to $60 \mathrm{~cm}$ in core 10 , and phosphorus concentrations are higher in units 4 and 3 in core 10 and 08 , respectively.

Concentrations of $\mathrm{Ca}, \mathrm{Na}, \mathrm{Sr}$, and $\mathrm{Y}$ increase from 50 to $40 \mathrm{~cm}$ in core 26 and are also relatively high at 70 and $25 \mathrm{~cm}$ (Figure 5). Aluminum, Fe, Mg, Mn, and Sc peak at 70 and $37 \mathrm{~cm}$, and $\mathrm{P}$ is high through much of the core. Concentrations of S are high near the base of the core and, along with Mo, have single-sample peaks at $130 \mathrm{~cm}$.

\section{Citrate/dithionite extracts}

Concentrations of many oxyhydroxide-associated elements in core 36 are lowest from 120 to $97 \mathrm{~cm}$ (Figure 6). Above $97 \mathrm{~cm}$, Fe and Mn increase, respectively, by 29\% to 530 $\pm 8 \mathrm{ppm}$ and by $23 \%$ to $10 \pm 0.08$ ppm. Aluminum, As, Ba, Co, Ni, Ti, U, V, Zn, and Zr also increase above $97 \mathrm{~cm}$. Oxyhydroxide-associated concentrations of $\mathrm{Au}, \mathrm{Cu}, \mathrm{Rb}, \mathrm{Sn}$, and $\mathrm{Sr}$ increase from $18 \mathrm{~cm}$ to the top of core 10, and other oxyhydroxide-associated elements increase upward above $60 \mathrm{~cm}$ in this core. Oxyhyroxide-associated elements increase from $35 \mathrm{~cm}$ to the top of core 08 . Calcium, $\mathrm{P}, \mathrm{Sc}, \mathrm{Sr}, \mathrm{Ti}, \mathrm{U}$, and V peak at $70 \mathrm{~cm}$ and $36 \mathrm{~cm}$ in core 26. Barium, $\mathrm{Co}, \mathrm{Cr}, \mathrm{Fe}, \mathrm{Rb}, \mathrm{Y}, \mathrm{Zn}$, and $\mathrm{Zr}$ increase upward in this core.

\section{Pyrophosphate extracts}

Organic-bound metals and \%C decrease from $97 \mathrm{~cm}$ to the top of core 36 (Figures 4 and 6). Cadmium, Co, Cr, Fe, Mn, Ni, S, Ti, U, V, and Zn co-vary with \%C. Pyrophosphateextractable $\mathrm{S}$ was detected only from the base of the core to $97 \mathrm{~cm}$. Calcium, $\mathrm{Mg}$, and $\mathrm{Sc}$ decrease upward in core 36. Uranium and V increase from 120 to $97 \mathrm{~cm}$; their peaks are, 
respectively, slightly below and above the peaks in Mo and S in the residual fraction.

Sodium and $\mathrm{Mn}$ are high from the base of the core to $65 \mathrm{~cm}$ and $\mathrm{As}$ and $\mathrm{Ba}$ concentrations are highest from 97 to $65 \mathrm{~cm}$. Iron, $\mathrm{Ni}$, and $\mathrm{Zn}$ peak above $65 \mathrm{~cm}$, and $\mathrm{K}$, $\mathrm{Rb}, \mathrm{Sr}$, and $\mathrm{U}$ increase from $65 \mathrm{~cm}$ to the top of the core. Most metals in core 10, as in core 36, co-vary with \%C. Cobalt, $\mathrm{Cu}, \mathrm{Mn}, \mathrm{Ni}, \mathrm{Pb}$, and $\mathrm{Zn}$ peak at $50 \mathrm{~cm}$, whereas $\mathrm{As}$, Ba, Ca, Cr, Mg. Sr, Ti, V, Y, and Zr peak at $60 \mathrm{~cm}$. Copper, Au, Cd, Cr, Ni, S, Sn, Ti, $\mathrm{U}, \mathrm{V}, \mathrm{Y}, \mathrm{Zn}$, and $\mathrm{Zr}$, generally decrease upward in core 08 ; $\mathrm{K}, \mathrm{Rb}$, and $\mathrm{Sr}$ increase upward in this core. Cadmium, $\mathrm{Co}, \mathrm{Mg}, \mathrm{Mn}, \mathrm{Ni}$, and $\mathrm{U}$ peak at $18 \mathrm{~cm}$ in core 08 , and $\mathrm{As}$, $\mathrm{Ba}, \mathrm{Ca}, \mathrm{Cd}$, and $\mathrm{Mn}$ are generally high from 18 to $10 \mathrm{~cm}$. Copper, $\mathrm{Mn}$, and $\mathrm{Zn}$ peak at 50$40 \mathrm{~cm}$ in core 26; no trends are evident in other organic-bound metals in this core (Figure 5).

\section{Data analysis}

Principal component analysis successfully grouped samples from the same stream, indicating that the sediment transported by each stream is different in composition and that source reconstructions using sediment geochemistry are possible. The first three principal components, which distinguish the four streams, explain $87 \%$ of the variance (Figure 7).

Principal components analysis of geochemical data from core 36 produced three significant factors that explain $83 \%$ of the variation. Factor 1 is interpreted to reflect a Slims River sediment source, with positive loadings on elements that are abundant in the Slims watershed, specifically $\mathrm{Ca}, \mathrm{Na}$, and $\mathrm{P}$, and negative loadings on elements with low concentrations in the watershed. Factor 2 has positive loadings on Ca and Sr, suggesting that a carbonate mineral occurs in the sediment. This factor is important above $45 \mathrm{~cm}$ and 
below $97 \mathrm{~cm}$ in core 36 . Two event laminae at 65 and $74 \mathrm{~cm}$ also load strongly on factor 2. Factor 3 has positive loadings on elements with high concentrations in Duke River sediments.

The first three factors explain $93 \%$ and $95 \%$ of the variance in the geochemical data from cores 08 and 10, respectively. It is difficult to ascribe any of the three factors to a particular sediment source, although two factors for each core appear to be weakly associated with Slims River and Bock's Creek sediments.

Results of the cluster analysis, Euclidean distances, discriminant analysis, and sediment unmixing models are generally consistent for core 36 . Discriminant analysis indicates two major periods of Duke River influence in core 36, one from the base of the core to $139 \mathrm{~cm}$ depth and another from 65 to $47 \mathrm{~cm}$ (Figure 8). A Bock's Creek influence is evident from 136 to $97 \mathrm{~cm}$ and a Silver Creek influence from 89 to $65 \mathrm{~cm}$. Euclidean distances give similar results. Constrained least squares analysis also indicates two periods of Duke River influence, one from the base of the core to $133 \mathrm{~cm}$ and another from 89 to $53 \mathrm{~cm}$ (Figure 9). The influence of Bock's Creek is reduced when Duke River's influence is high, but is evident from 133 to $97 \mathrm{~cm}$ and 73 to 36 . A Silver Creek signature is evident until Slims River begins to dominate the sediment supply at $47 \mathrm{~cm}$. Constrained least squares analysis and Euclidean distances reveal Slims-type intervals at 203 and $159 \mathrm{~cm}$, but discriminant analysis assigns only the sample at $203 \mathrm{~cm}$ to Slims River. Cluster analysis indicates that these intervals are unique but does not associate them with the same sediment source as unit 3. The inclusion of the glaciolacustrine silt sample in the data set does not significantly alter the results of the constrained least squares analysis. Constrained least squares analysis was also performed on the data after 
removing Mo and $\mathrm{S}$, which are incorporated in authigenic sulfides, but no differences were evident in the results. The results from core 10 are similar to those from core 36.

Discriminant analysis indicates that core 08 is dominated by Duke River sediment. Only the surface sample and the sample at $56-55 \mathrm{~cm}$ have a Silver Creek source. Likewise, constrained least squares analysis suggests that most samples from core 08 have a Duke River source. A Silver Creek influence is evident at the base of the core, but decreases upward. A Bock's Creek sediment signature is present throughout the core, increasing in the upper two samples.

\section{Discussion}

\section{Sediment sources}

Residual element abundances in core 36 change at 153, 97, and $65 \mathrm{~cm}$ depth (Figure 4). Based on average sedimentation rates, these changes date to about 2750, 1300, and 300 cal yr BP. The most recent change is marked by a gradual increase in $\mathrm{Ca}, \mathrm{Na}$, and $\mathrm{P}$ from $65 \mathrm{~cm}$ to the top of the core. These elements are characteristic of the Slims River source, which is consistent with the inception of meltwater inputs from Kaskawulsh Glacier about 300 cal yr BP. Elevated Na and P suggest an influx of unweathered rock flour. Phosphorus, as a limiting nutrient, is transformed within a few thousand years into bioavailable forms through soil development (Filippelli et al. 2006). Similarly, $\mathrm{Na}$ is easily leached during weathering, but is not readily sedimented through authigenic reactions, adsorption, or biological uptake (Engstrom and Wright 1984). The upward increase in $\mathrm{Ca}, \mathrm{Na}$, and $\mathrm{P}$ reflects the rapid progradation of the Slims River delta from the present Kaskawulsh-Slims drainage divide to its present location. The advance of the 
delta in historic time was rapid, averaging about $42 \mathrm{~m} \mathrm{yr}^{-1}$ from 1899 to 1970 (Rampton and Shearer 1978b).

Constrained least squares analysis and Euclidean distances assign the samples at 203 and $159 \mathrm{~cm}$ to a Slims River source, largely based on their elevated $\mathrm{Ca}, \mathrm{Na}$, and $\mathrm{P}$ concentrations (Figures 8 and 9). Discriminant analysis also identifies the sample at 203 cm as Slims-type sediment. These results suggest that Kaskawulsh Glacier meltwater flowed into Kluane Lake at least twice before 300 cal yr BP. Based on average sedimentation rates, the earlier meltwater inputs date to about 4000 and 2800 cal yr BP. Glaciers in the Purcell, Coast, Rocky, and Selkirk mountains advanced around $4000 \mathrm{cal}$ yr BP (Gardner and Jones 1985; Osborn and Karlstrom 1989; Osborn et al., 2007; Wood and Smith 2004), and Kaskawulsh Glacier and other glaciers in the St. Elias Mountains advanced about 2800 cal yr BP (Borns and Goldthwait 1966; Denton and Stuiver 1966; Denton and Karlén 1977).

The gradient of Kaskawulsh River directly downstream of Kaskawulsh Glacier is steeper than that of Slims River. Slims River is thus vulnerable to being pirated by Kaskawulsh River. Only the presence of glacier ice and outwash in the divide area prevents this piracy (Figure 1). Any pre-Little Ice Age advance of Kaskawulsh Glacier that brought the toe of the glacier close to the present divide would probably route meltwater away from Kaskawulsh River and into Kluane Lake. The weakness of the Slims sediment signal at 203 and $159 \mathrm{~cm}$ is likely due to the distance $(25 \mathrm{~km})$ of core site 36 from the point of meltwater inflow to Kluane Lake. Peaks in these elements occur in sediment intervals with lower organic carbon contents than the rest of the core, suggesting rapid sedimentation, which is consistent with a new meltwater source. 
Constrained least squares analysis indicates two major periods of Duke River influence on Kluane Lake sediments. When Kluane Lake was $10 \mathrm{~m}$ or more lower than today, Duke River may have flowed into the lake south of Brooks Arm, strengthening the Duke River signal in cores 36 and 08. A possible stream channel extends southeast along the axis of Brooks Arm and may have carried Duke River during one or more periods of low lake level (Robert Gilbert, personal communication, 2004). In addition, imbrication in the Duke River fan sediments indicates that flow was to the southeast some time between 2000 and $600 \mathrm{cal}$ yr BP (Clague et al. 2006).

At times, Duke River either flowed north away from Kluane Lake, as it does today, and did not affect the lake, or it discharged into an isolated basin near Talbot Arm. Dating and geochemistry of core 36 indicate that the river flowed into Kluane Lake from about 4850 to 2400 cal yr BP, when its influence began to decline. Little or no Duke River sediment entered the lake between about 2100 and 1300 cal yr BP. A Duke River influence again becomes evident about $1300 \mathrm{cal} \mathrm{yr} \mathrm{BP}$ and continues to about $300 \mathrm{cal} \mathrm{yr}$ BP (Figure 10).

The beginning of the most recent period of Duke River discharge into Kluane Lake coincides with a major change in the climate of southern Yukon. Anderson et al. (2005) documented shifts in the North Pacific Index (NPI), a measure of sea-level pressure over the North Pacific, at about 2800 and 1300 cal yr BP. North Pacific pressure anomalies control climate in southwest Yukon. Analysis of modern historical climate data from Burwash Landing reveals a negative correlation of the NPI $\left(\mathrm{r}^{2}=0.65\right)$ with annual temperature and a positive correlation $\left(\mathrm{r}^{2}=0.59\right)$ with winter precipitation. 
Warming around $1300 \mathrm{yr} \mathrm{BP}$, inferred from independent paleo-climate data (Anderson et al. 2005), may have thawed permafrost in soils in the watershed. Mildly reducing conditions in the catchment may have resulted from melt of stagnant ice. In a mildly reducing environment, manganese has a greater solubility than iron; an increase in Mn relative to $\mathrm{Fe}$ is observed from $97-65 \mathrm{~cm}(1300$ to $300 \mathrm{yr} \mathrm{BP})$ in all geochemical fractions.

Constrained least squares analysis indicates an upward decrease in sediment of Silver Creek provenance above $97 \mathrm{~cm}$ (1300 yr BP). This trend is consistent with Rampton and Shearer's (1978b) interpretation of the stratigraphy of Kluane Lake sediments off the Slims River delta. Their subbottom acoustic survey revealed two sharply bounded sediment units: an upper unit derived from Slims River and a lower unit deposited by Silver Creek and other local streams.

\section{Anoxia in Kluane Lake}

Constrained least squares analysis of geochemical data from core 36 suggests that Duke River either did not discharge into Kluane Lake from about 2100 to 1300 cal yr BP, or that its flow was reduced. Because Slims River did not exist at this time, the level of Kluane Lake was considerably lower than today and the basin may have been closed. Sediments deposited at this time contain black laminae, consistent with deposition under reducing conditions. Reducing conditions could develop from permanent or nearpermanent stratification (meromixis) in the lake. Meromictic and anoxic conditions are not commonly associated with low stands of oligotrophic lakes, but semi-permanent stratification could develop in Kluane Lake under some conditions. Groundwater entering the lake from the south and west is rich in dissolved solutes $\left(150-3000 \mathrm{mg} \mathrm{L}^{-1}\right.$; Harris 
1990). Density stratification could develop in the low-level lake in the absence of mixing and influx of fresh Slims and Duke River waters. A concentration of total dissolved solids of roughly $340 \mathrm{mg} \mathrm{L}^{-1}$ is enough to cause a greater density difference in water masses than that created by temperature differences. Pienitz et al. (2000) reported anoxic conditions in a shallow Yukon lake due to high $\mathrm{Mg}^{2+}$ and $\mathrm{SO}_{4}{ }^{2-}$ concentrations, similar to concentrations of these ions in groundwater flowing into Kluane Lake $\left(10 \mathrm{mg} / \mathrm{L} \mathrm{Mg}^{2+}\right.$ and $50 \mathrm{mg} / \mathrm{L} \mathrm{SO}_{4}{ }^{2-}$ ).

Under low oxygen conditions, redox-sensitive elements can complex with organic acids or precipitate as insoluble oxyhydroxides or insoluble metal sulfides. Elements involved in reactions catalyzed by free $\mathrm{H}_{2} \mathrm{~S}$ or deposited as organic complexes include Cr, U, and V (Calvert and Pedersen 1993, Algeo and Maynard 2004). Elements that can form insoluble sulfides in reducing conditions include $\mathrm{Cd}, \mathrm{Co}, \mathrm{Mo}, \mathrm{Ni}, \mathrm{Pb}$, and $\mathrm{Zn}$ (Calvert and Pedersen 1993, Algeo and Maynard 2004). The presence or absence of these elements in sediments can provide information on paleo-redox conditions in Kluane Lake.

\section{Molybdenum}

Molybdenum and S concentrations co-vary $\left(\mathrm{r}^{2}=0.91\right)$ from 153 to $97 \mathrm{~cm}$ in core 36 , suggesting uptake of Mo in pyrite (Figure 4). The associated increase in organic carbon is not likely due to increased productivity, but rather to preservation of organic matter in a low-oxygen environment. Molybdenum can be concentrated in anoxic bottom waters through redox cycling in the water column. $\mathrm{MoO}_{4}{ }^{2-}$ is easily scavenged by manganese oxyhydroxides (Berrang and Grill 1974; Adelson et al. 2001) in oxygenated waters. Subsequent dissolution of manganese oxyhydroxides in low-oxygen environments 
releases $\mathrm{MoO}_{4}{ }^{2-}$ into solution. Sedimentation of Mo seems to require the formation of an intermediary species, thio-oxymolybdate $\left(\mathrm{MoO}_{\mathrm{x}} \mathrm{S}_{4-\mathrm{x}}{ }^{2}\right)(\mathrm{Helz}$ et al. 1996). Molybdenum can then be sedimented by scavenging on iron sulfides or by forming bonds with sulfurized organic matter (Helz et al. 1996; Adelson et al. 2001; Tribovillard et al. 2004). Free $\mathrm{H}_{2} \mathrm{~S} / \mathrm{HS}^{-}$is necessary for thiomolybdate to form, thus euxinic conditions are required in the water column, rather than simply reducing conditions in the sediments. Although conversion to thiomolybdates is catalyzed by mineral surfaces (Helz et al. 1996), Crusius et al. (1996) noted that Mo does not seem to accumulate in modern marine environments that are suboxic or anoxic, but rather only in marine environments that are euxinic. Thus, molybdenum fixation probably occurs more rapidly at the sediment-water interface than at depth in the sediment. It is unlikely that Kluane Lake is productive enough to produce strong reducing conditions within sediments after burial.

\section{Copper}

Copper can be precipitated in anoxic or euxinic environments as an independent sulfide phase, in solid solution with iron sulfides, or as an organic complex (Morse and Luther 1999). Copper co-varies with sulfur from 130 to $97 \mathrm{~cm}$ (2200 to $1300 \mathrm{yr} \mathrm{BP}$ ) in core 36, perhaps due to authigenic precipitation. The increase in $\mathrm{Cu}$ from 97 to $65 \mathrm{~cm}$ (1300 to $300 \mathrm{yr} \mathrm{BP}$ ) in the same core probably records a change in sediment source.

\section{Vanadium and uranium}

Pyrophosphate-extractable V and U increase from 130 to $97 \mathrm{~cm}$ (2200 to $1300 \mathrm{yr} \mathrm{BP})$ in core 36 (Figure 6). Pyrophosphate-extractable U also increases from $65 \mathrm{~cm}$ (300 yr BP) to the top of the core. The latter increase may be the result of a change in sediment source because $\mathrm{U}$ also increases in the residual fraction. Citrate/dithionite-extractable $\mathrm{V}$ and $\mathrm{U}$ 
decrease from 130 to $97 \mathrm{~cm}$. Vanadium and $\mathrm{U}$ are known to concentrate in organic sediments under mildly reducing and euxinic conditions (Emerson and Huested 1991; Klinkhammer and Palmer 1991; Algeo and Maynard 2004). Vanadium, like Mo, can be concentrated in anoxic bottom waters (Wehrli and Stumm 1989).

Vanadium occurs as the vanadyl ion $\left(\mathrm{VO}^{2+}\right)$ under mildly reducing conditions. It can be precipitated as insoluble oxides or hydroxides under strongly reducing conditions (Wanty and Goldhaber 1992). The reduced form of $\mathrm{U}$ is the uranyl ion $\mathrm{UO}^{2+}$. No enrichment of either element as authigenic phases is evident in Kluane Lake sediments. Residual V is highly correlated with $\mathrm{Zn}$ throughout core $36\left(\mathrm{r}^{2}=0.80\right)$. Vanadium correlates with $\mathrm{Ti}$ in the Slims interval $\left(65-0 \mathrm{~cm} ; \mathrm{r}^{2}=0.97\right)$ and from $159 \mathrm{~cm}$ to the base of the core $\left(r^{2}=0.88\right)$. It has a lower correlation with Ti from 153 to $97 \mathrm{~cm}\left(\mathrm{r}^{2}=0.62\right)$, but is highly correlated with Fe over this section of the core $\left(r^{2}=0.92\right)$. Residual $U$ correlates with $\mathrm{K}$ and $\mathrm{Al}$ over the length of the core $\left(\mathrm{r}^{2}=0.86\right.$ and 0.84 , respectively), and U correlates with Fe in unit $1\left(r^{2}=0.83\right)$. These strong correlations suggest that, through much of the core, residual $\mathrm{V}$ and $\mathrm{U}$ are associated with non-authigenic fractions and thus are likely controlled by sediment provenance. The absence of enrichment in the authigenic phase may be due to competitive complexation of the dissolved species with organic matter. Vanadyl and uranyl ions commonly form organic ligands (Templeton and Chasteen 1980; Lewan and Maynard 1982; Emerson and Huested 1991; Klinkhammer and Palmer 1991; Algeo and Maynard 2004), and complexation of U and V with organic material under suboxic and anoxic conditions may leave the dissolved species unavailable for precipitation in sediments under reducing conditions. The requirement 
that conditions be only mildly reducing may explain peaks in $\mathrm{V}$ and $\mathrm{U}$ prior to peaks in Mo and S.

\section{Chromium, cobalt, nickel, and zinc}

Chromium, Co, Ni, and Zn co-vary in all Kluane Lake cores. In core 36, Co, Cr, and Ni in the residual phase correlate strongly with $\mathrm{Mg}$ in unit $3\left(\mathrm{r}^{2}=0.92,0.86\right.$, and 0.9, respectively), and in units 1 and $2\left(\mathrm{r}^{2}=0.91,0.87\right.$, and 0.91 , respectively). From the base of the core to $97 \mathrm{~cm}, \mathrm{Zn}$ is strongly correlated with $\mathrm{Al}\left(\mathrm{r}^{2}=0.62\right), \mathrm{Fe}\left(\mathrm{r}^{2}=0.91\right)$, and $\mathrm{V}$ $\left(r^{2}=0.96\right)$. These strong correlations suggest that the elements in the residual phase reflect sediment provenance.

Cobalt, $\mathrm{Ni}$, and $\mathrm{Zn}$ can be precipitated as independent sulfide phases in anoxic environments, but the process is kinetically slow for Co and Ni (Morse and Luther 1999). Cobalt and Ni can be incorporated into pyrite, but structural and thermodynamic properties may restrict $\mathrm{Zn}$ and prevent $\mathrm{Cr}$ from co-precipitating altogether (Huerta-Diaz and Morse 1992; Morse and Luther 1999). Huerta-Diaz and Morse (1992) noted that Mo is more rapidly incorporated into pyrite than $\mathrm{Co}$ and $\mathrm{Ni}$. Concentrations of $\mathrm{Cu}$ and $\mathrm{Mo}$ in Kluane Lake waters are greater than concentrations of Co, and Ni (J. Bunbury and K. Gajewski, unpublished data), which may account for the elevated values of authigenic Mo and $\mathrm{Cu}$ in Kluane Lake sediments.

Cobalt, $\mathrm{Cr}, \mathrm{Ni}$, and $\mathrm{Zn}$ correlate with \% $\mathrm{C}$ in the pyrophosphate-extractable fraction in core $36\left(r^{2}=0.68,0.52,0.76\right.$, and 0.55 , respectively) and in the citrate/dithionite-extractable fractions below $97 \mathrm{~cm}$. The association of $\mathrm{Ni}$ with the organic fraction suggests deposition under reducing conditions in the hypolimnion. In the reduced state, dissolved $\mathrm{Ni}$ is preferentially incorporated into organic tetrapyrrole 
complexes (Lewan and Maynard 1982). Tetrapyrrole complexes degrade faster than other types of organic matter, thus preservation requires deposition in a low-oxygen environment. An association of $\mathrm{Cr}$ and $\mathrm{Ni}$ with the organic fraction is consistent with the observation of Algeo and Maynard (2004) that these elements are associated with organic matter in non-sulfide anoxic and euxinic waters. The presence of $\mathrm{Co}$ and $\mathrm{Zn}$ in the organic fraction suggests that both elements can complex with organic matter under reducing conditions.

Zinc can complex with humic and fulvic acids in anoxic environments (Achterberg et al. 1997). The brief increase in $\mathrm{Zn}$ pyrophosphate at $65 \mathrm{~cm}$ in core 36 may record in-wash of terrestrial organic matter as Kluane Lake rose during the Little Ice Age. Calcium, Fe, and Ni also increase at this depth, possibly for the same reason.

\section{Iron and manganese}

Iron and Mn co-vary in core 36. The residual phases probably represent both detrital and authigenic minerals; both elements can form minerals through diagenetic precipitation. Iron and Mn oxyhydroxides are soluble in their reduced states and are insoluble under oxic conditions (Engstrom and Wright 1984). Thus concentrations of both elements should be low in the sediments during periods of anoxia.

The presence of Fe and Mn oxyhydroxides from 120 to $97 \mathrm{~cm}$ in core 36 does not necessarily argue against euxinic conditions (Figure 6). The normal sequence of reduction reactions is $\mathrm{O}_{2}, \mathrm{NO}_{3}{ }^{-}, \mathrm{MnO}_{\mathrm{x}}, \mathrm{Fe}(\mathrm{OH})_{3}$, and $\mathrm{SO}_{4}{ }^{2-}$. The next electron acceptor must be almost used up before the reaction moves on to the next stage (Schlesinger 1997). This sequence, however, may not always occur in natural environments due to spatial heterogeneity and variable concentrations of available electron receptors. Kelly et 
al. (1982) observed some sequential reduction in seasonally stratified lakes, where $\mathrm{O}_{2}$ and $\mathrm{NO}_{3}{ }^{-}$reduction ceased before the lakes overturned but all other reactions proceeded simultaneously. Sulfate concentrations in Kluane Lake and in the lakes that surround it are up to four orders of magnitude greater than dissolved Fe and Mn concentrations, and nitrate is only present in trace concentrations.

Complete dissolution of oxyhydroxides on the floor of Kluane Lake may require lengthy exposure to reducing conditions. Iron and Mn oxyhydroxides could still be deposited at such times because Kluane Lake is relatively shallow. Dissolution would surely occur, but oxyhydroxides would have a comparatively short transit through anoxic or euxinic bottom waters. The presence of Fe and Mn oxyhydroxides may also be an artifact of sampling. Sediments were sampled with a 1-cm diameter plug, and most samples contained both dark and light laminae.

Iron and Mn can be strongly complexed by organic matter (Engstrom and Wright 1984). Iron and Mn pyrophosphates increase with organic carbon from 153 to $97 \mathrm{~cm}$ in core 36. Reduction of oxyhydroxides may have liberated Fe and Mn, which were subsequently complexed with organic matter.

Core 10 is only slightly shallower than core 36 (33 m vs. $36 \mathrm{~m})$, thus its sediments probably would have experienced bottom water anoxia too. Core 10 sulfur concentrations are elevated from 80 to $50 \mathrm{~cm}$ (3600 to $200 \mathrm{yr} \mathrm{BP}$ ), and redox-sensitive elements (Co, $\mathrm{Cu}, \mathrm{Ni}, \mathrm{Pb}$, and $\mathrm{Zn}$ ) peak at $50 \mathrm{~cm}$. Citrate extractions of $\mathrm{As}, \mathrm{Ba}, \mathrm{Co}, \mathrm{Fe}, \mathrm{Mn}, \mathrm{Ni}, \mathrm{U}, \mathrm{V}$, $\mathrm{Y}, \mathrm{Zn}$, and $\mathrm{Zr}$ are relatively low in this section of the core.

Core 08 is shallower than cores 36 and 10 and does not show the same associations with redox-sensitive elements. Pyrophosphate extractable metals decrease 
upward from near the base of the core. Secondary peaks of $\mathrm{Co}, \mathrm{Ni}$, and $\mathrm{U}$ occur at $17 \mathrm{~cm}$. The trends may reflect higher concentrations of organic matter near the base of the core, associated with shallower water. The peak at $17 \mathrm{~cm}(300 \mathrm{yr} \mathrm{BP})$ marks the base of the upper unit in core 08 and possibly records in-wash of terrestrial organic matter during the Kluane Lake high stand.

A return to mixing in the basin

A return to oxygenated conditions in Kluane Lake about 1300 cal yr BP is suggested by a rapid increase in Fe and Mn oxyhydroxides and associated trace elements at $97 \mathrm{~cm}(1300$ yr BP) in core 36 (Figure 6). Citrate/dithionite-extractable Fe and Mn increase, respectively, 29\% (to $530 \pm 8 \mathrm{ppm}$ ) and $23 \%$ (10 $\pm 0.08 \mathrm{ppm})$ at this level. Arsenic, Ba, $\mathrm{Co}, \mathrm{Ni}, \mathrm{Ti}, \mathrm{U}, \mathrm{V}$, and $\mathrm{Zr}$ increase from $29 \%$ to $260 \%$, probably because they were scavenged by oxyhydroxides. Similarly, Fe and Mn oxyhydroxide concentrations in the citrate/dithionite extracts of cores 10 and 08 increase above, respectively, $35 \mathrm{~cm}$ and 25 $\mathrm{cm}(1300$ and $600 \mathrm{yr} \mathrm{BP})$.

Constrained least squares analysis suggests that Duke River began to flow into Kluane Lake about 1300 yr BP. Increased input of fresh cold water may have initiated mixing in the lake and re-oxygenated its bottom waters.

Aluminum, $\mathrm{Mg}, \mathrm{P}$, and $\mathrm{Rb}$ concentrations in citrate extracts increase at $65 \mathrm{~cm}$ in core 36 . They also increase in the residual fraction, implying a change in source material rather than a change in oxidation state. Phosphorus sedimentation and retention in sediments are influenced by Fe and Mn oxyhydroxides (Engstrom and Wright 1984). Phosphorus does not correlate with either element throughout core 36 , suggesting that its 
sedimentation may not be controlled by Fe or Mn for much of Kluane Lake's history. Phosphorus concentrations in Kluane Lake sediments appear to be related to a change in supply rather than redox state. Citrate-extractable $\mathrm{P}$ increases above $108 \mathrm{~cm}$ and again above $65 \mathrm{~cm}$ (1600 and $300 \mathrm{yr}$ BP). Co-variation of citrate-extractable P and citrateextractable $\mathrm{Sr}$ and $\mathrm{Ca}$ suggests that carbonates may control their concentrations.

\section{Summary}

Changes in the flow of Duke and Slims rivers affected the level of Kluane Lake and its redox state during the late Holocene. Duke River at times flowed into the lake and at other times bypassed it to the north. Sediment geochemical data indicate that Duke River flowed into Kluane Lake before $2100 \mathrm{cal}$ yr BP and between about 1300 and $200 \mathrm{cal}$ yr BP. Slims River has flowed into Kluane Lake for the past several centuries and, over this period, has deposited a thick wedge of sediments in the southern part of the basin (Clague et al. 2006). Older Slims River sediment, dating to about 4000 and $2800 \mathrm{cal} \mathrm{yr} \mathrm{BP,} \mathrm{is}$ present in one core in the southern part of the lake. Fluctuations in discharge and location of both rivers appear to be associated with climate fluctuations. Climate warmed around $1300 \mathrm{cal}$ yr BP, and the glacier advanced at about 4000, 2800, and $300 \mathrm{cal}$ yr BP.

Kluane Lake was low and stratified when Duke River and all meltwater from Kaskawulsh Glacier bypassed the lake. Meromixis led to anoxic and eventually euxinic conditions in the hypolimnion, possibly causing precipitation of Mo and $\mathrm{Cu}$ sulfides. The lack of enrichment of many other redox-sensitive elements can be explained by their low availability in the water column or by competitive complexation with humic and fulvic acids. 


\section{Acknowledgements}

We thank Melanie Grubb and Robert Gilbert for valuable field and laboratory assistance,

Rick Routledge and Carl Swartz for discussion of statistical methods, and Lito Arocena

for analytical help. Research funding was provided by a Natural Sciences and

Engineering Research Council of Canada (NSERC) Postgraduate Scholarship to

Brahney; NSERC Discovery Grants to John Clague, Brian Menounos, and Tom Edwards;

the Geological Society of America; and the Northern Scientific Training Program of Indian and Northern Affairs Canada.

\section{References}

Achterberg EP, van der Berg CMG, Boussemart M, Davison W 1997 Speciation and cycling of trace metals in Esthwaite water: A productive English lake with seasonal deep-water anoxia. Geochim Cosmochim Acta 61: 5233-5253

Adelson JM, Helx GR, Miller CV 2001 Reconstructing the rise of recent coastal anoxia; molybdenum in Chesapeake Bay sediments. Geochim Cosmochim Acta 65: 237-252

Algeo TJ, Maynard JB 2004 Trace-element behavior and redox facies in core shales of Upper Pennsylvanian Kansas-type cyclotherms. Chem Geol 206: 289-318

Anderson L, Abbott MB, Finney BP, Burns SJ 2005 Regional atmospheric circulation change in the North Pacific during the Holocene inferred from lacustrine carbonate oxygen isotopes, Yukon Territory, Canada. Quaternary Res 64: 21-35

Berrang PG, Grill EV 1974 The effect of manganese oxide scavenging on molybdenum in Saanich Inlet, British Columbia. Mar Chem 2: 125-148 
Borns HW Jr, Goldthwait RP 1966 Late-Pleistocene fluctuations of Kaskawulsh Glacier, southwestern Yukon Territory, Canada. Am J Sci 264: 600-619

Bostock HS 1969 Kluane Lake, Yukon Territory; its drainage and allied problems. Geol Surv Can Pap 69-28

Boyle JF 2001 Inorganic geochemical methods in palaeolimnology. In Last, WM, Smol, JP, eds, Tracking Environmental Change Using Lake Sediments, Volume 2: Physical and Geochemical Techniques. Kluwer Acad Publ, Dordrecht, The Netherlands, pp. $83-141$

Brahney J 2007 Paleolimnology of Kluane Lake. MSc thesis, Simon Fraser Univ, Burnaby, BC

Bryan ML 1972 Variations in quality and quantity of Slims River water, Yukon Territory. Can J Earth Sci 9: 1469-1478

Bryan WB, Finger LW, Chayes F 1969 Estimating proportions in petrographic mixing equations by least-squares approximation. Science 163: 926-927

Calvert SE, Pedersen TF 1993 Geochemistry of recent oxic and anoxic marine sediments: Implications for the geologic record. Mar Geol 113: 67-88

Campbell RB, Dodds CJ 1982 Geology, Kluane Lake map area (115F and G). Geol Surv Can Open File 829.

Clague JJ 1981 Landslides at the south end of Kluane Lake, Yukon Territory. Can J Earth Sci 18: 959-971

Clague JJ, Evans SG, Rampton VN, Woodsworth GJ 1995 Improved age estimates for the White River and Bridge River tephras, western Canada. Can J Earth Sci 32: 11721179 
Clague JJ, Luckman BH, Van Dorp RD, Gilbert R, Froese D, Jensen BJL, and Reyes AV 2006 Rapid changes in the level of Kluane Lake in Yukon Territory over the last millennium. Quaternary Res 66: 342-355

Collins AL, Walling DE, Leeks GJL 1997 Source type ascription for fluvial suspended sediment based on a quantitative composite fingerprinting technique. Catena 29:1-27

Collins AL, Walling DE, Leeks GJL 1998 Use of composite fingerprints to determine the provenance of the contemporary suspended sediment load transported by rivers. Earth Surface Processes Landforms 23: 31-52

Crusius J, Calvert S, Pedersen T, Sage D 1996 Rhenium and molybdenum enrichments in sediments as indicators of oxic, suboxic and sulfidic conditions of deposition. Earth Planet Sci Lett 145: 65-78

Denton GH, Karlén W 1977 Holocene glacial and tree-line variations in the White River valley and Skolai Pass, Alaska and Yukon Territory. Quaternary Res 7: 63-111

Denton GH, Stuiver M 1966 Neoglacial chronology, northeastern St. Elias Mountains, Canada. Am J Sci 264: 577-599

Emerson SR, Huested SS 1991 Ocean anoxia and the concentration of molybdenum and vanadium in seawater. Mar Chem 34: 177-196

Engstrom DR, Wright HE Jr 1984 Chemical stratigraphy of lake sediments as a record of environmental change. In Haworth EY, Lund JWG, eds, Lake Sediments and Environmental History, Studies in Paleolimnology and Paleoecology. Leicester Univ Press 11: 11-67 
Filippelli GM, Souch C, Menounos B, Slater-Atwater S, Jull T, Slaymaker O 2006 Alpine lake records reveal the impact of climate and rapid climate change on the biogeochemical cycling of soil nutrients. Quaternary Res 66: 158-166

Gardner JS, Jones NK 1985 Evidence for a Neoglacial advance of the Boundary Glacier, Banff National Park, Alberta. Can J Earth Sci 22: 1753-1755

Helz GR, Miller CV, Charnock JM, Mosselmans JFW, Pattrick RAD, Garner CD, Vaughan DJ 1996 Mechanism of molybdenum removal from the sea and its concentration in black shales: EXAFS evidence. Geochim Cosmochim Acta 60: $3631-3642$

Huerta-Diaz MG, Morse JW 1992 Pyritization of trace metals in anoxic marine sediments. Geochim Cosmochim Acta 56: 2681-2702

Kelly CA, Rudd JWM, Cook RB, Schindler DW 1982 The potential importance of bacterial processes in regulating rate of lake acidification. Limnol Oceanogr 27: 868882

Klinkhammer GP, Palmer MR 1991 Uranium in the ocean where it goes and why. Geochim Cosmochim Acta 55: 1799-1806

Lewan MD, Maynard JB 1982 Factors controlling the enrichment of vanadium and nickel in the bitumen of organic sedimentary rocks. Geochim Cosmochim Acta 46: 25472560

Morse JW, Luther GW III 1999 Chemical influence on trace metal-sulfide interaction in anoxic sediments. Geochim Cosmochim Acta 63: 3373-3378 
Mosser C 1991 Relationship between sediments and their igneous source rocks using clay mineral multi-element chemistry the Cenozoic lacustrine Anloua Basin (Adamaoua, Cameroon). Chem Geol 90: 319-342

Natural Resources Canada 2003 The atlas of Canada: Facts about Canada: Lakes. http://atlas.gc.ca/site/english/learningresources/facts/lakes.html\#yukon (accessed January 2005)

Osborn GD, Karlstrom ET 1989 Holocene moraine and paleosol stratigraphy, Bugaboo Glacier, British Columbia. Boreas 18: 311-322

Osborn G, Menounos B, Koch J, Clague J, and Vallis, V. 2007. Multi-proxy record of Holocene glacier history of the Spearhead and Fitzsimmons ranges, southern Coast Mountains, British Columbia. Quaternary Sci Rev 26: 479-493.

Pienitz R, Smol JP, Last WM, Leavitt PR, Cumming BF 2000 Multi-proxy Holocene paleoclimatic record from a saline lake in the Canadian Subarctic. Holocene 10: 673686

Rampton VN, Shearer JM 1978a Bottom and sub-bottom conditions at Kluane Lake, Teslin River, and Nisutlin Bay pipe line crossings. Terrain Analysis Mapping Serv, Stittsville, ON

Rampton VN, Shearer JM 1978b The geology and limnology of Kluane Lake, Yukon Territory, I Preliminary assessment. Terrain Analysis Mapping Serv, Stittsville, ON

Ross GJ, Wang C 1993 Extractable Al, Fe, Mn and Si. In Carter, MR, ed, Soil Sampling and Methods of Analysis for Canadian Society of Soil Science. Lewis Publ, Boca Raton, FL, pp. 239-246 
Schlesinger WH 1997 Biogeochemistry: An analysis of global change. Academic Press, London

Templeton GD III, Chasteen ND 1980 Vanadium fulvic acid chemistry: Conformational and binding studies by electron spin probe techniques. Geochim Cosmochim Acta 44: $741-752$

Tribovillard N, Riboulleau A, Lyons T, Baudin F 2004 Enhanced trapping of molybdenum by sulfurized marine organic matter of marine origin in Mesozoic limestones and shales. Chem Geol 213: 385-401

Wanty RB, Goldhaber MB 1992 Thermodynamics and kinetics of reactions involving vanadium in natural systems: Accumulation of vanadium in sedimentary rocks. Geochim Cosmochim Acta 56: 1471-1483

Wehrli B, Stumm W 1989 Vanadyl in natural waters: Adsorption and hydrolysis promote oxygenation. Geochim Cosmochim Acta 53: 69-77

Wood C, Smith DJ 2004 Dendroglaciological evidence for a Neoglacial advance of the Saskatchewan Glacier, Banff National Park, Canadian Rocky Mountains. Tree-Ring Res 60: 59-65 
Table 1 Radiocarbon ages from Kluane Lake cores

\begin{tabular}{lllll}
\hline $\begin{array}{l}{ }^{14} \mathrm{C} \text { age } \\
\left({ }^{14} \mathrm{C} \mathrm{yr} \mathrm{BP}\right)\end{array}$ & Laboratory no & $\begin{array}{l}\text { Core no. and } \\
\text { sample depth }\end{array}$ & Material & $\begin{array}{l}\text { Calendar age }{ }^{2} \\
(\text { cal yr BP })\end{array}$ \\
\hline $1660 \pm 40$ & Beta-200708 & $08,50.5 \mathrm{~cm}$ & wood & $1500-1630,1660-1690$ \\
$1180 \pm 40$ & Beta-200709 & $26,177 \mathrm{~cm}$ & wood & $980-1180$ \\
$1310 \pm 40$ & Beta-200710 & $31,103 \mathrm{~cm}$ & wood & $1170-1300$ \\
$1180 \pm 40$ & Beta-213014 & $26,139 \mathrm{~cm}$ & wood & $980-1180$ \\
$3910 \pm 80$ & TO-12468 & $36,219 \mathrm{~cm}$ & spruce needle & $4090-4570$ \\
& & & and twig & \\
\hline
\end{tabular}

${ }^{1}$ Radiocarbon laboratory: Beta-Beta Analytic Inc.; TO-IsoTrace Radiocarbon Laboratory (University of Toronto).

${ }^{2}$ Determined from the calibration data set IntCal98 (Stiuver et al. 1998); calibrated age ranges are reported as $\pm 2 \sigma$. 


\section{Figure captions}

Fig. 1. Kluane Lake, southwest Yukon Territory. Modified from Clague et al. (2006) with permission from Elsevier.

Fig. 2. Kluane Lake bathymetry and core locations. Cores described in this paper are designated by black dots. Modified from Clague et al. (2006) with permission from Elsevier.

Fig. 3. Lithostratigraphy of Kluane Lake and Cultus Bay cores.

Fig. 4. Representative concentrations of elements in the residual sediment fraction of core 36 .

Fig. 5. Representative concentrations of elements in the residual, cithrate/dithionite, and pyrophosphate fractions of core 26.

Fig. 6. Representative concentrations of elements in the citrate/dithionite and pyrophosphate extracts from core 36 .

Fig. 7. Principal component bi-plots showing separation of sediment sources.

Fig. 8. Sediment sources for samples from cores 08 , 10, and 36 based on discriminant analysis and Euclidian distances.

Fig. 9. Constrained least squares results for core 36. Note the two major periods of Duke River influence. The Slims River source dominates the sediment from $42 \mathrm{~cm}$ to the surface.

Fig. 10 Reconstructions of Kluane Lake at three times, showing inferred flow directions of Duke River. The photographs show representative sediment deposited at each time. 


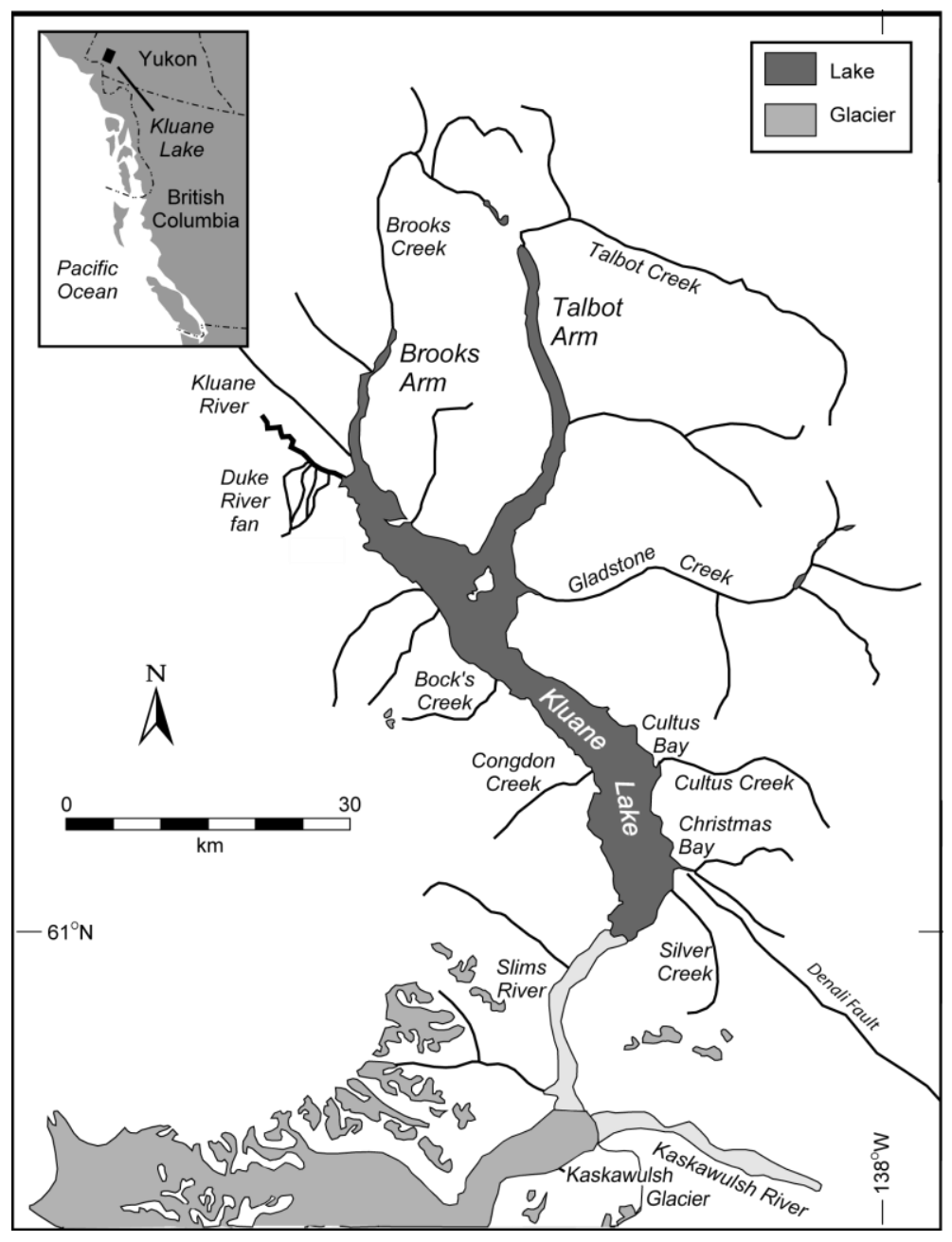




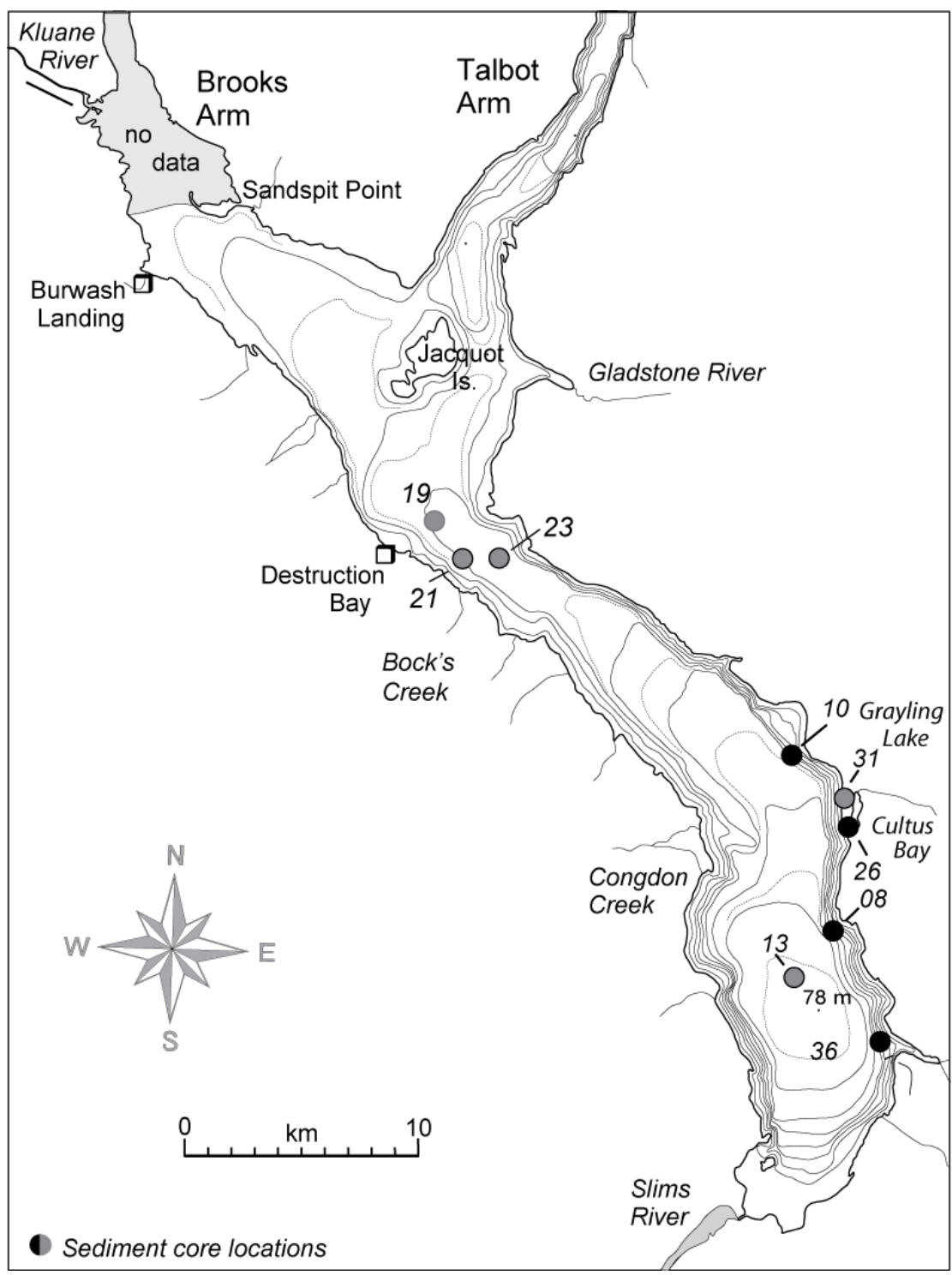




\section{Kluane Lake}

36

08

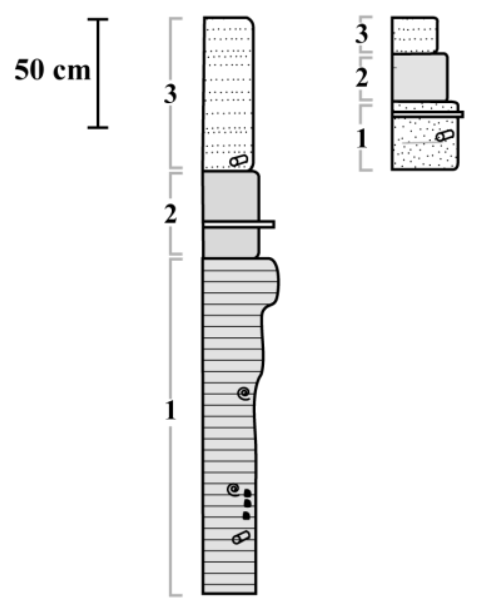

10

\section{Cultus Bay}

26

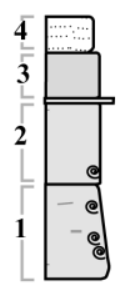

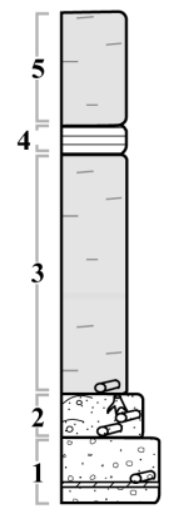

Laminated silt and find sand

Massive silt and fine sand

Laminated clayey silt

$\therefore$ Coarse sand

Fine to laminated silt and fine sand

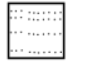

medium sand

.

Fine sand

$\checkmark$ Wood fragment

A Root in growth position

Forest litter @ Gastropod

- Stone 
Core 36

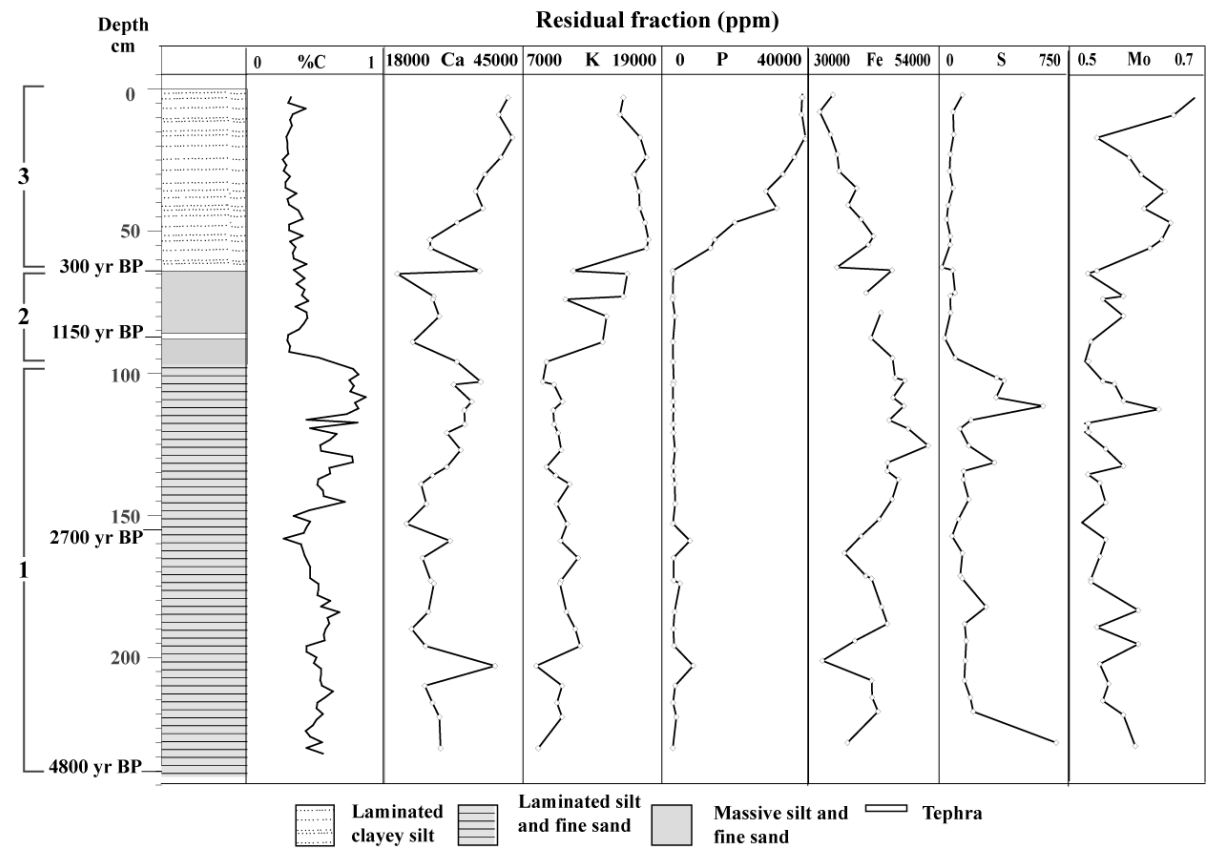




\section{Core 26}

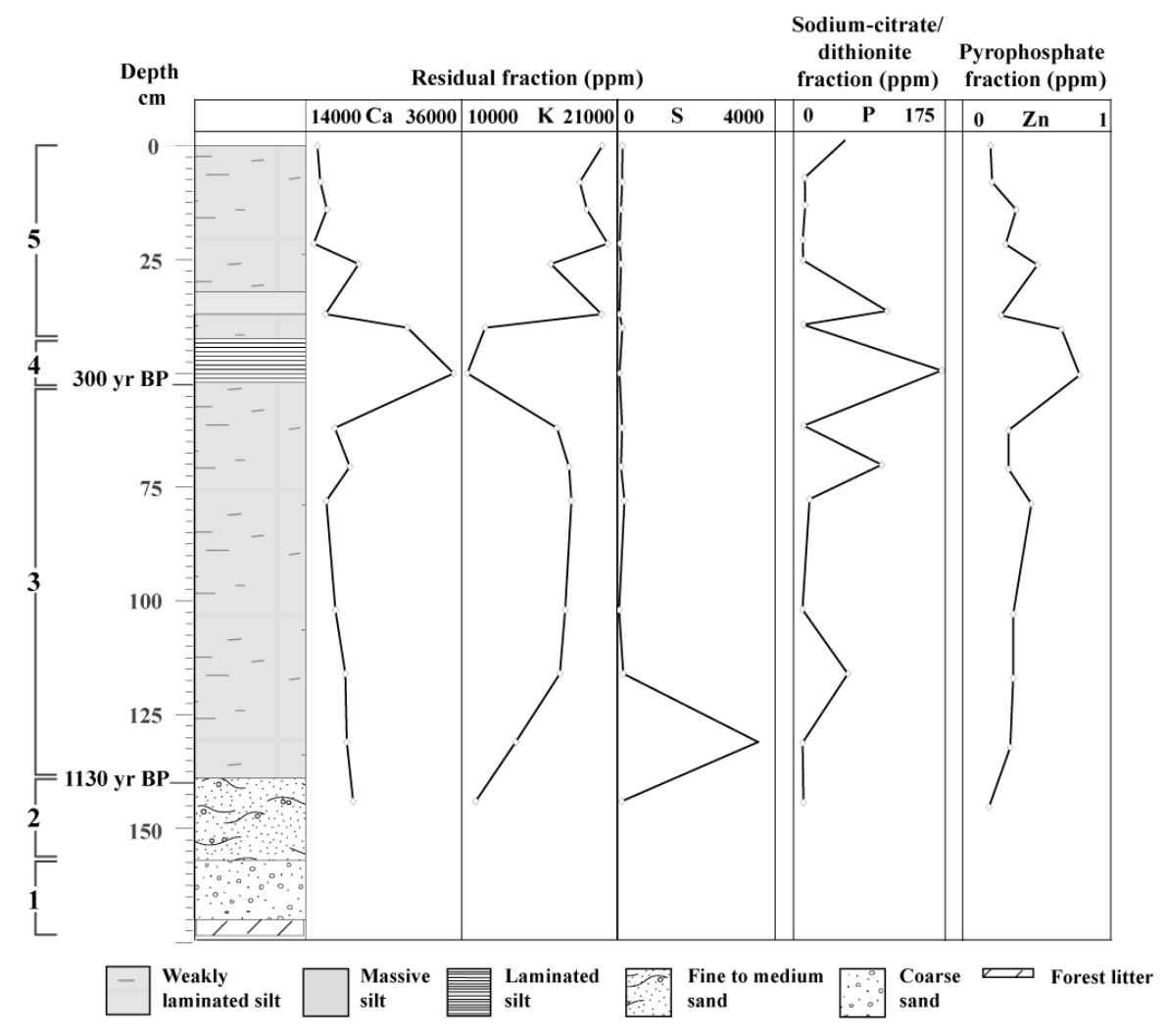


Core 36

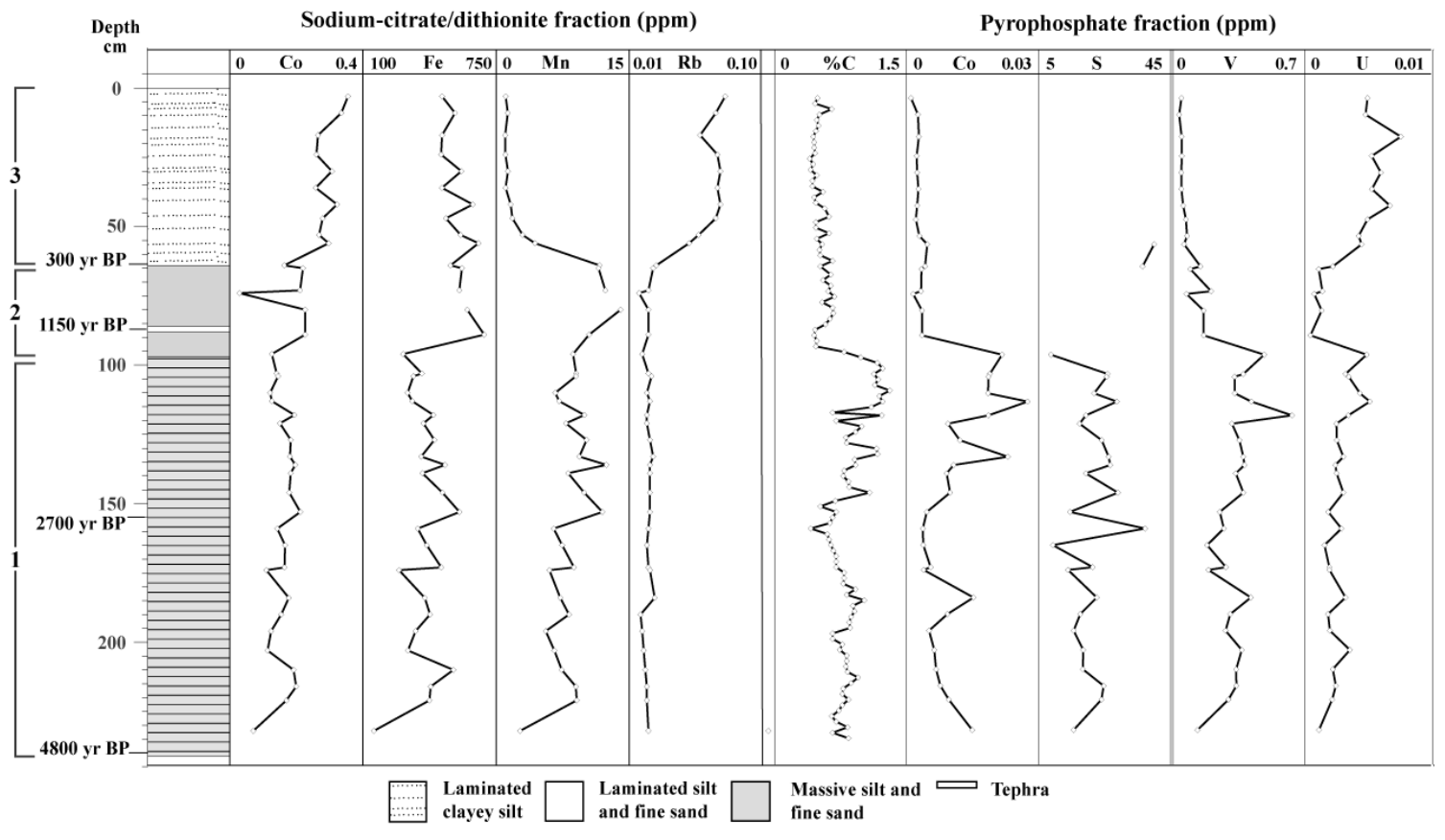




\section{Principal Components Analysis}

\section{Suspended stream and floodplain sediment}

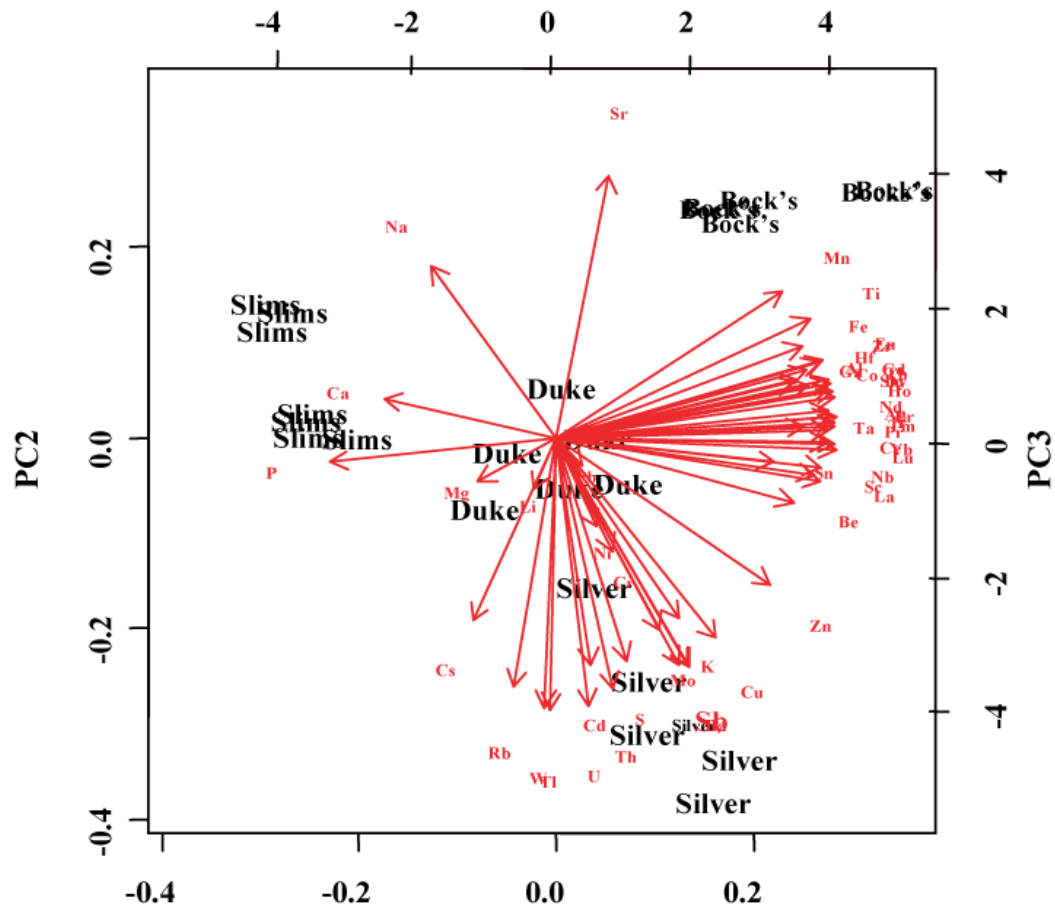

PC1

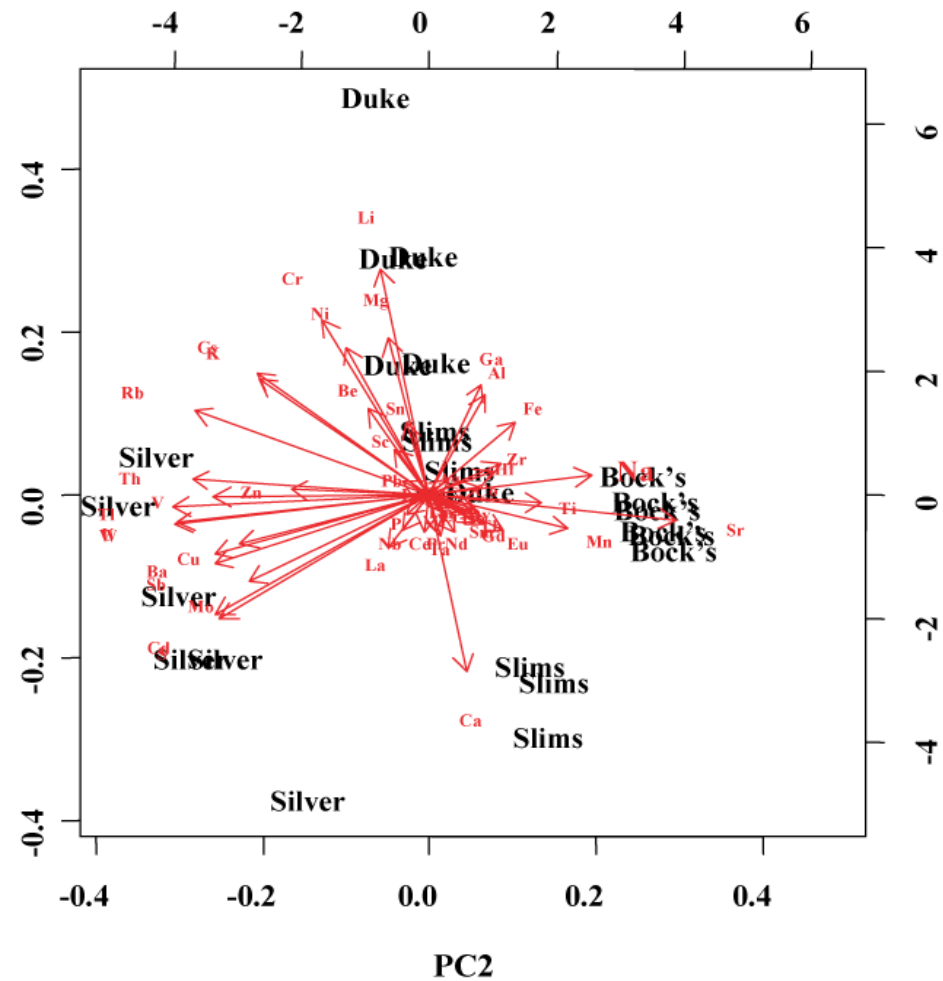




\section{Core 36}

\begin{tabular}{|c|c|c|c|}
\hline \multirow[t]{11}{*}{ yr BP } & Depth & Discriminant & \begin{tabular}{|l} 
Euclidean \\
Distance
\end{tabular} \\
\hline & $3-2$ & Slims & Slims \\
\hline & $9-10$ & Slims & Slims \\
\hline & $\mid 17-18$ & Slims & Slims \\
\hline & $24-25$ & Slims & Slims \\
\hline & $30-31$ & Slims & Slims \\
\hline & $36-37$ & Slims & Duke \\
\hline & $42-43$ & Slims & |Duke \\
\hline & $47-48$ & Duke & |Duke \\
\hline & $53-54$ & Duke & Duke \\
\hline & $56-57$ & Duke & Silver \\
\hline \multirow{6}{*}{$300-$} & 64 & Duke & Bocks \\
\hline & $67-68$ & Silver & Silver \\
\hline & 73-74 & Silver & Silver \\
\hline & 74 & Duke & Bocks \\
\hline & $80-81$ & Silver & Silver \\
\hline & $89-90$ & Silver & Bocks \\
\hline \multirow{13}{*}{$1300-$} & $96-97$ & Duke & Bocks \\
\hline & $103-104$ & Bocks & Bocks \\
\hline & $105.5-106.5$ & Bocks & Bocks \\
\hline & $110-111$ & Duke & Silver \\
\hline & 113-114 & Silver & Silver \\
\hline & $118-119$ & Bocks & Bocks \\
\hline & 121-122 & Bocks & Bocks \\
\hline & $127-128$ & Bocks & Bocks \\
\hline & 133-134 & Bocks & |Duke \\
\hline & $136-137$ & Bocks & |Duke \\
\hline & $139-140$ & |Duke & ||Duke \\
\hline & $146-147$ & |Duke & |Duke \\
\hline & $153-154$ & ||Duke & |Duke \\
\hline \multirow[t]{11}{*}{$2750-$} & $159-160$ & Duke & Slims \\
\hline & $165-166$ & Duke & Duke \\
\hline & $173-174$ & |Duke & |Duke \\
\hline & $178-179$ & |Duke & |Duke \\
\hline & $184-185$ & |Duke & |Duke \\
\hline & 190-191 & Duke & |Duke \\
\hline & 196-197 & Silver & ||Duke \\
\hline & 201-202 & Duke & Duke \\
\hline & 203-204 & Slims & Slims \\
\hline & $210-211$ & |Duke & ||Duke \\
\hline & 216-217 & |Duke & Duke \\
\hline $4850-$ & $232-233$ & Duke & Slims \\
\hline
\end{tabular}

\section{Core 26}

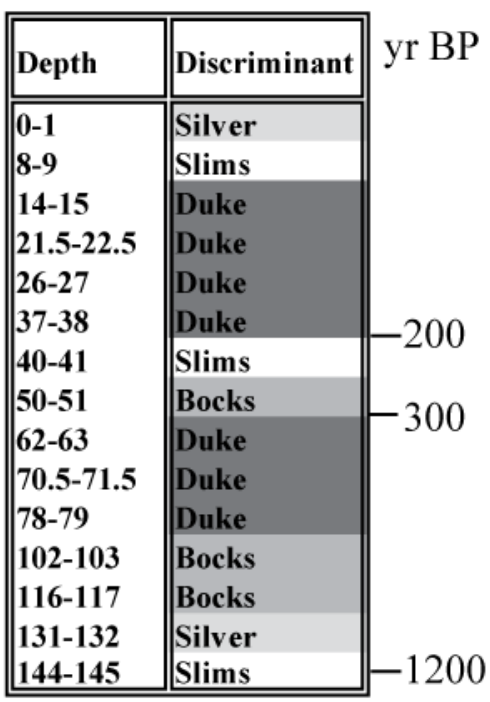

\section{Core 10}

\begin{tabular}{|c|c|}
\hline Depth & Discriminant \\
\hline $2-3$ & Slims \\
\hline $9-10$ & Slims \\
\hline $16-17$ & Silver \\
\hline $21-22$ & Bocks \\
\hline $50-51$ & Duke \\
\hline $60-61$ & Duke \\
\hline $80-81$ & Duke \\
\hline 103-104 & Slims \\
\hline
\end{tabular}

\section{Core 08}

\begin{tabular}{|c|c|}
\hline Depth & Discriminant \\
\hline $1-2$ & Silver \\
\hline $\mid 10-11$ & Duke \\
\hline $18-19$ & Duke \\
\hline $25-26$ & Duke \\
\hline $36-37$ & Duke \\
\hline $55-56$ & Slims \\
\hline
\end{tabular}




\section{Core 36}

Constrained Least Squares

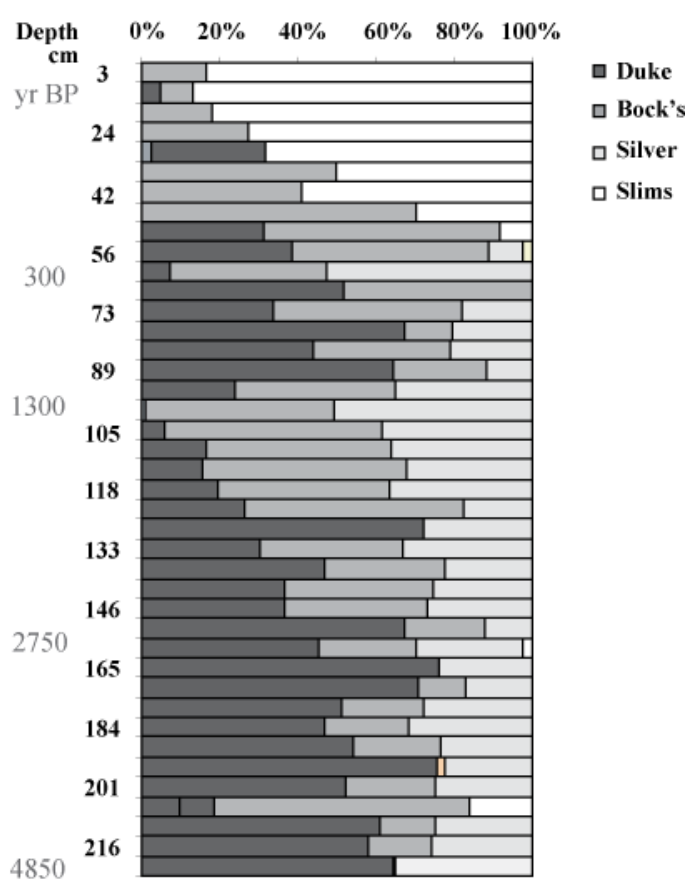




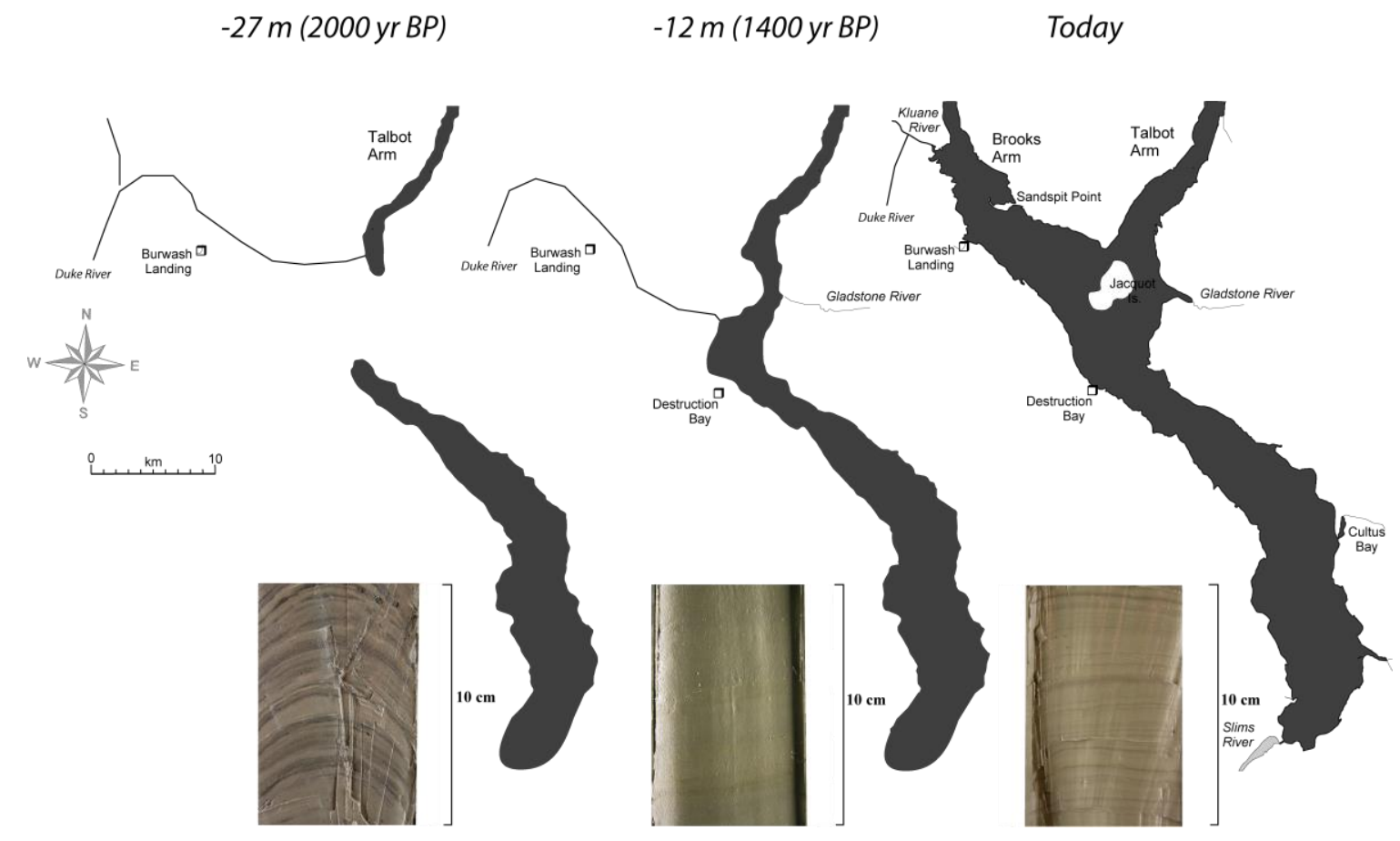

